\title{
Synthesis, X-ray crystal structure, DNA binding and Nuclease activity of lanthanide(III) complexes of 2-benzoylpyridine acetylhydrazone
}

\author{
KARREDDULA RAJA, AKKILI SUSEELAMMA and KATREDDI HUSSAIN REDDY* \\ Department of Chemistry, Sri Krishnadevaraya University, Anantapur 515 003, India \\ e-mail: khussainreddy@yahoo.co.in
}

MS received 5 April 2016; revised 1 June 2016; accepted 1 June 2016

\begin{abstract}
Lanthanide(III) complexes of general formula $\left[\mathrm{La}(\mathrm{BPAH})_{2}\left(\mathrm{NO}_{3}\right)_{3}\right]$ and $\left[\mathrm{Ce}(\mathrm{BPAH})_{2}\left(\mathrm{NO}_{3}\right)\left(\mathrm{H}_{2} \mathrm{O}\right)_{2}\right]$ $2 \mathrm{NO}_{3} \cdot \mathrm{H}_{2} \mathrm{O}$ (where, BPAH = 2-benzoylpyridine acetyl hydrazone), were synthesized and characterized by elemental analysis, molar conductance, IR spectroscopy and single crystal X-ray diffraction and Hirschfeld studies. The central metal ion is 12-coordinate in lanthanum complex and 10-coordinated in the cerium complex. The coordination polyhedra around the lanthanum and cerium were found to have distorted icosahedron and distorted bicapped square antiprism respectively. DNA binding and nuclease activity of these complexes were also investigated in the present work.
\end{abstract}

Keywords. Lanthanide(III)complexes; 2-benzoylpyridine acetyl hydrazone; X-ray crystallography; Hirshfeld; DNA studies.

\section{Introduction}

The fascinating growth of lanthanide coordination chemistry and supramolecular chemistry during the last two decades have contributed to great success in various fields like hybrid materials, ${ }^{1}$ luminescent sensor ${ }^{2}$ and therapeutic applications. ${ }^{3}$

The lanthanide metal ions have larger ionic-radii, higher coordination number (6-12) compared to transition metal ions, ${ }^{4}$ and their versatile coordination chemistry have offered potential applications in the design of intelligent lanthanide complexes ${ }^{5,6}$ Lanthanum complexes have been used as active agents in the treatment of bone resorption disorders. ${ }^{7,8}$ In recent years, metal complexes with pyridine based hydrazones have drawn immense attention due to their versatile applications. These complexes show oxidase biomimetic catalytic activity, anti-cancer and anti-microbial activities. ${ }^{9-12}$

The design of small complexes that bind and react with DNA is one of the interesting activities of bioinorganic chemist. Hence it is important to investigate more efficient drugs that target DNA. In recent years, ${ }^{13-15}$ there is some interest towards synthesis, DNA interaction and nuclease activity of lanthanide (III) complexes.

However, to the best of our knowledge, much attention was not paid to explore the DNA interaction and nuclease activities of rare earth metal complexes

\footnotetext{
*For correspondence
}

derived from pyridine based hydrazones. Recently, we have reported ${ }^{16,17}$ synthesis, spectral properties and DNA binding and nuclease activity of lanthanide(III) complexes of pyridine hydrazones. In the light of the above, and in continuation of our previous work, herein we report synthesis, crystal structure, DNA binding and cleavage activity of $\mathrm{La}(\mathrm{III})$ and $\mathrm{Ce}$ (III) complexes with 2-benzoylpyridine acetyl hydrazone (BPAH).

\section{Experimental}

\subsection{Materials and methods}

All the reagents used in the synthesis of ligand (viz., 2benzoylpyridine, and acetyl hydrazine) and lanthanide nitrates were purchased from Sigma-Aldrich chemicals and were used without further purification. The solvents were obtained after being distilled by standard method. Lanthanide salts were stored in desiccators to prevent hydration. Agarose used in gel electrophoresis was purchased from Sigma-Aldrich. CT-DNA, pBR 322 were purchased from Genie Biolabs, Bangalore, India.

\subsection{Synthesis of 2-benzoylpyridine acetyl hydrazone (BPAH)}

The ligand, 2-benzoylpyridine acetyl hydrazone (BP$\mathrm{AH}$ ) was prepared by following the procedure given in literature. ${ }^{18}$ 


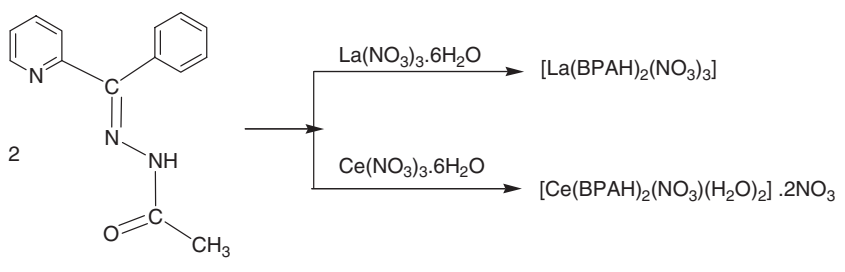

Scheme 1. Synthetic route for the lanthanide complexes.

\subsection{Preparation of Complexes}

The lanthanide complexes were prepared by mixing hot ethanolic solution of BPAH ( $2 \mathrm{mmol}, 0.478 \mathrm{~g}$ ) and $\mathrm{La}\left(\mathrm{NO}_{3}\right)_{3} \cdot 6 \mathrm{H}_{2} \mathrm{O}(1 \mathrm{mmol})$ dissolved in ethanol in $2: 1$ ratio in a clean $100 \mathrm{~mL}$ round bottom flask and the contents were refluxed at $60^{\circ} \mathrm{C}$ on water bath for 1-2 days. The complex was not formed immediately. Then the reaction mixture was kept aside at room temperature and after two days, the product was formed. It was collected by filtration, washed with small quantity of ether. On slow evaporation of ethanol solutions of complexes, dark yellow coloured needle shape single crystals of cerium complex and white coloured single crystals of lanthanum complex were obtained at room temperature. These crystals were suitable for X-ray diffraction studies. Synthetic route for the synthesis of complexes is given in Scheme 1.

2.3a $\left[\mathrm{La}(\mathrm{BPAH})_{2}\left(\mathrm{NO}_{3}\right)_{3}\right](1):$ [Yield: $74 \%$, Color: white] Elemental analysis: Found./(Cal) (\%): C: 41.87/(41.86), H: 3.25/(3.26), N: 15.70/(15.69); IR data $\left(\mathrm{cm}^{-1}\right): v(\mathrm{~N}-\mathrm{H}) 3247, v(\mathrm{C}=\mathrm{O}) 1655, v(\mathrm{C}=\mathrm{N}) 1524$, $v_{1}\left(\mathrm{NO}_{3}^{-}\right) 1474, v_{2}\left(\mathrm{NO}_{3}\right)$ 1033, $v_{3}\left(\mathrm{NO}_{3}^{-}\right) 825, v_{4}\left(\mathrm{NO}_{3}^{-}\right)$ 1288.

$2.3 \mathrm{~b} \quad\left[\mathrm{Ce}(\mathrm{BPAH})_{2}\left(\mathrm{NO}_{3}\right)\left(\mathrm{H}_{2} \mathrm{O}\right)_{2}\right] 2 \mathrm{NO}_{3}(2)$ : [Yield: 71\%, Color: Yellow] Elemental analysis: Found./(Cal) (\%): C: 39.99/(40), H: 3.57/(3.59), N: 15/(14.99); IR data $\left(\mathrm{cm}^{-1}\right): v(\mathrm{O}-\mathrm{H}) 3426, v(\mathrm{~N}-\mathrm{H}) \quad 3217, v(\mathrm{C}=\mathrm{O})$ $1622, v(\mathrm{C}=\mathrm{N}) 1530, v_{1}\left(\mathrm{NO}_{3}^{-}\right) 1465, v_{2}\left(\mathrm{NO}_{3}\right)$ 1026, $v_{3}\left(\mathrm{NO}_{3}^{-}\right) 819, v_{4}\left(\mathrm{NO}_{3}^{-}\right) 1288, v_{0}\left(\mathrm{NO}_{3}\right) 1384$.

\section{Physical measurements}

The elemental analyses $(\mathrm{C}, \mathrm{H}$ and $\mathrm{N})$ were performed using a Heraeus Vario EL III Carlo Erba 1108 instrument. Molar conductivity measurements were carried out with a systronic model 303 direct-reading conductivity bridge using DMF solution $\left(10^{-3} \mathrm{M}\right)$ at $28^{\circ} \mathrm{C}$. UVVis. analysis was carried out in DMF with a Perkin Elmer UV Lambda -50 spectrophotometer. FT-IR spectra (KBr discs, 4000-400 $\mathrm{cm}^{-1}$ ) was obtained with a Perkin Elmer spectrum 100 - spectrophotometer.

\section{$3.1 X$-ray crystallography}

X-ray crystallographic data and cell refinement parameters were collected on Enraf Nonius CAD4-MV31 diffractometer, (SAIF-IIT Madras) using graphite monochromated $\mathrm{MoK} \alpha$ radiation at room temperature $293 \mathrm{~K}$. The data collected were reduced using the SAINT program. ${ }^{19}$ The structures were resolved by direct method using SHELXS-86, ${ }^{20}$ and refined by fullmatrix least square on $\mathrm{F}^{2}$ (SHELXL-97). ${ }^{21}$ The graphic tool used was DIAMOND for windows. ${ }^{22}$ ORTEP3 were used to generate the ORTEP diagram. ${ }^{23}$

\subsection{Hirshfeld surface analysis}

The Hirshfeld surfaces represented by $d_{\text {norm }}$, shape index and 2-D fingerprint plots were calculated using Crystal Explorer 3.1. ${ }^{24}$

For each point on the Hirshfeld surface, two parameters are defined: $d_{e}$ from the point to the nearest nucleus external to the surface and $d_{i}$ is the distance from the point to the nearest nucleus internal to the surface. The normalized contact distance, $d_{\text {norm }}$, based on both $d_{e}$ and $d_{i}$, and the $v d W$ radius of the atom, given by an equation:

$$
d_{n o r m}=\frac{d_{i}-r_{i}^{V d w}}{r_{i}^{V d w}}+\frac{d_{e}-r_{e}^{V d w}}{r_{e}^{V d w}}
$$

Here, $r_{i}^{V d w}$ and $r_{e}^{V d w}$ are the internal and external van der Waals radius of the atom. The combination of $d_{e}$ and $d_{i}$ in the form of a 2-D fingerprint plot provides summary of intermolecular contacts in the crystal. ${ }^{25}$

\subsection{DNA binding and cleavage experiments}

DNA binding and cleavage experiments were done as described before. ${ }^{16}$

\section{Result and discussion}

The elemental analysis results are consistent with the proposed molecular formulae of ligand and complexes. $\mathrm{La}(\mathrm{III})$ and $\mathrm{Ce}$ (III) complexes are stable in air, nonhygroscopic nature. The complexes are soluble in dimethylformamide and dimethyl sulfoxide, but they are not soluble in non-polar organic solvents. The molar conductivity values are found to be 14 and $138 \Omega^{-1}$ $\mathrm{cm}^{-2} \mathrm{~mol}^{-1}$ for La and Ce complexes. The values suggest non-electrolytic and 1:2 electrolytic nature ${ }^{26}$ of $\mathrm{La}$ and $\mathrm{Ce}$ complexes, respectively. 


\subsection{IR Spectroscopy}

The FT- IR spectra of lanthanide complexes in the region $4000-400 \mathrm{~cm}^{-1}$ were analysed in comparison with that of the spectrum of metal free BPAH. The free ligand has characteristic IR bands at 1666 and 1586 $\mathrm{cm}^{-1}$ due to amido carbonyl and azomethine group respectively. These bands are shifted to lower 1655(La), $1622(\mathrm{Ce})$ and $1524(\mathrm{La}) 1530(\mathrm{Ce}) \mathrm{cm}^{-1}$ in IR spectra complexes indicating the participation of azomethine nitrogen and amido oxygen in chelation. ${ }^{27} \mathrm{~A}$ strong band is observed in the IR spectrum of Ce complex at 3426 and is assigned to $v(\mathrm{O}-\mathrm{H})$ vibration of coordinated water molecule. The vibrational band at $3198 \mathrm{~cm}^{-1}$ can be assigned to the $v(\mathrm{~N}-\mathrm{H})$ for the free ligand. This band is observed in the range $3217-3247 \mathrm{~cm}^{-1}$ in the IR spectrum of complexes. The presence of both $v(C=O)$ and $v(\mathrm{~N}-\mathrm{H})$ vibrational bands in the IR spectra of complexes indicates that BPAH acts as neutral ligand in complex formation. The pyridine ring in-plane deformation mode is observed at $621 \mathrm{~cm}^{-1}$ in the spectrum of BPAH. This band is shifted to higher frequencies $629(\mathrm{La})$ and $631(\mathrm{Ce}) \mathrm{cm}^{-1}$ in the spectra of lanthanide complexes indicating coordination of the heterocyclic aromatic nitrogen. ${ }^{27}$

The vibrational bands that appeared at 1474-65 $\mathrm{cm}^{-1}$ $\left(v_{1}\right), 1288 \mathrm{~cm}^{-1}\left(v_{4}\right), 1026-33 \mathrm{~cm}^{-1}\left(v_{2}\right)$ and 819-25 $\mathrm{cm}^{-1}\left(v_{3}\right)$ in the spectrum of Ln-complexes are assigned to the presence of bidentate $\left[\Delta v=v_{1}-v_{4}=177\right.$ and $186 \mathrm{~cm}^{-1}$ ] nitrate ligand. ${ }^{28,29}$ The presence of band around $1384 \mathrm{~cm}^{-1}$ in the IR spectrum of Ce complex indicates the presence of ionic nitrate which is in agreement with the results of the conductivity experiments.

\subsection{Description of the structure of $\left[\mathrm{La}(\mathrm{BPAH})_{2}\left(\mathrm{NO}_{3}\right)_{3}\right]$}

The $\left[\mathrm{La}(\mathrm{BPAH})_{2}\left(\mathrm{NO}_{3}\right)_{3}\right]$ has been structurally characterized by single crystal X-ray diffraction. It crystallizes in monoclinic, space group $\mathrm{C} 2 / \mathrm{c}$ with six $\left[\mathrm{La}(\mathrm{BPAH})_{2}\left(\mathrm{NO}_{3}\right)_{3}\right]$ molecules in each unit cell as shown in Figure 1. Crystal data and structure refinement parameters are shown in Table 1. Important bond lengths and bond angles are presented in Tables 2 and 3 respectively. Molecular structure of $\left[\mathrm{La}(\mathrm{BPAH})_{2}\left(\mathrm{NO}_{3}\right)_{3}\right]$ is shown in Figure 2. The BPAH ligand is coordinated to central metal atom to form two five membered rings. Two five membered rings are planar but not in one plane. Dihedral angle between the two five membered rings is $15.67^{\circ}$. Dihedral angle between the two ligand main planes is $79.98^{\circ}$.

The dihedral angle between the pyridine and phenyl ring in the same hydrazone ligand is $78.82^{\circ}$ which indicates phenyl ring is twisted out of pyridine ring plane so as to avoid $\mathrm{H}-\mathrm{H}$ repulsion.

$\left[\mathrm{La}\left(\mathrm{NO}_{3}\right)_{3}(\mathrm{BPAH})_{2}\right]$ has a $C 2$ symmetry, and the $C 2$ axis passes through the $\mathrm{La}(\mathrm{III})$ ion, one nitrate ion with nitrogen $\mathrm{N} 4$ and non-coordinated oxygen $\mathrm{O} 3$. As in the title compound, one nitrate group is situated on one side of the mean plane of the organic ligand(s), with remaining two nitrate groups on the opposite side.

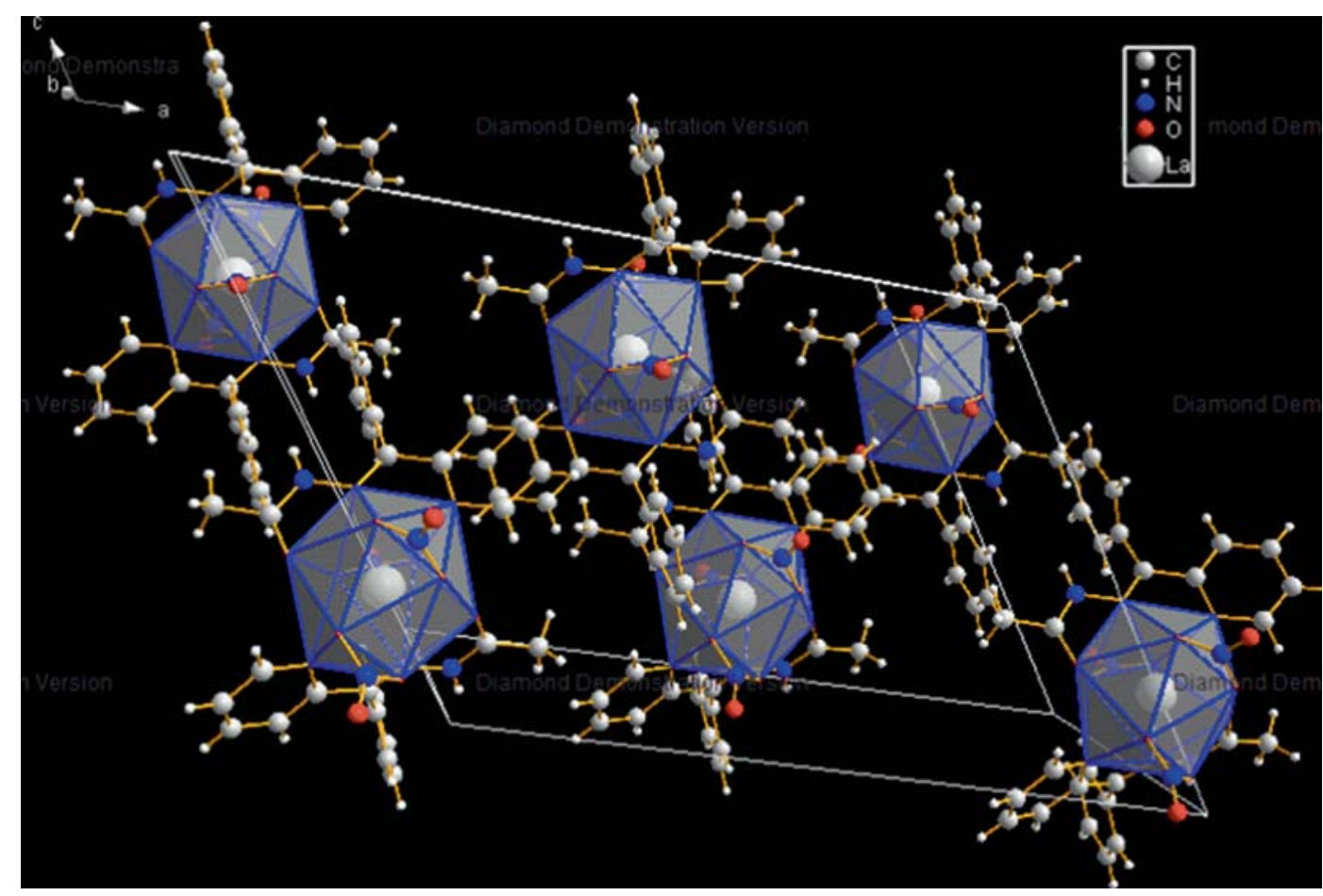

Figure 1. Unit cell structure of $\left[\mathrm{La}(\mathrm{BPAH})_{2}\left(\mathrm{NO}_{3}\right)_{3}\right]$ with distorted icosahedrons around $\mathrm{La}(\mathrm{III})$ center. 
Table 1. Selected crystallographic data for $\mathbf{1}$ and $\mathbf{2}$.

Formula

Formula weight (M)

$T(\mathrm{~K})$

Wavelength $(\mathrm{Mo} \mathrm{K} \alpha)(\AA)$

Crystal system

space group

Lattice constants

$a(\AA)$

$b(\AA)$

$c(\AA)$

$\alpha\left({ }^{\circ}\right)$

$\beta\left({ }^{\circ}\right)$

$\gamma\left({ }^{\circ}\right)$

$V\left(\mathrm{~A}^{3}\right)$

Z

Calculated density $\rho\left(\mathrm{Mg} \mathrm{m}^{-3}\right)$

Absorption coefficient $\mu\left(\mathrm{mm}^{-1}\right)$

$F(000)$

Crystal size (mm)

$\theta$ range for data collection $\left(^{\circ}\right)$

Limiting indices

Reflections collected / unique

Completeness to $\theta(\%)$

Absorption correction

Max and min transmission

Refinement method

Data / restraints / parameters

Goodness-of-fit on $F^{2}$

Final Rindices $[I>2 \sigma(I)]$

$R$ indices (all data)

Largest diff. peak and hole $\left(\mathrm{e}^{-3}\right)$

$$
\begin{gathered}
\mathrm{C}_{28} \mathrm{H}_{26} \mathrm{La} \mathrm{N}_{9} \mathrm{O}_{11} \\
803.49 \\
293(2) \\
0.71073 \\
\text { Monoclinic } \\
C 2 / c
\end{gathered}
$$

$$
\text { 22.0822(4) }
$$

$11.2226(2)$

16.1814(3)

90

$124.7290(10)$

90

$3295.70(10)$

$$
4
$$

1.619

1.368

1608

$0.25 \times 0.20 \times 0.20$

2.24 to 25.00

$-26 \leq h \leq 25$,

$-13 \leq k \leq 13$,

$-19 \leq l \leq 19$

$14219 / 2908[R($ int $)=0.0256]$ 99.9

Semi-empirical from equivalents 0.7865 and 0.7136

Full-matrix least-squares on $F^{2}$ 2908 / 0 / 227 1.066

$R_{1}=0.0182, w R_{2}=0.0464$

$R_{1}=0.0195, w R_{2}=0.0472$

0.366 and -0.294

\author{
$\mathrm{C}_{28} \mathrm{H}_{30} \mathrm{Ce} \mathrm{N}_{9} \mathrm{O}_{13}$ \\ 840.73 \\ 293(2) \\ 0.71073
}

Orthorhombic,

$P 2{ }_{1} 2_{1} 2_{1}$

$10.0805(4)$

$14.5765(3)$

23.0043(8)

90

90

90

$3380.21(19)$

4

1.652

1.425

1692

$0.35 \times 0.30 \times 0.20$

2.21 to 25.00

$-10 \leq h \leq 11$,

$-17 \leq k \leq 11$,

$-26 \leq l \leq 27$

$17317 / 5938[R($ int $)=0.0306]$ 99.9

Semi-empirical from equivalents 0.7956 and 0.6024

Full-matrix least-squares on $F^{2}$ $5938 / 82 / 524$ 1.025

$R_{1}=0.0239, w R_{2}=0.0466$

$R_{1}=0.0282, w R_{2}=0.0483$

0.288 and -0.247
Table 2. Selected bond lengths ( $\AA$ ) for the structure of $\mathbf{1}$.

\begin{tabular}{llll}
\hline $\mathrm{N}(1)-\mathrm{La}(1)$ & $2.8271(17)$ & $\mathrm{N}(2)-\mathrm{La}(1)$ & $2.7901(16)$ \\
$\mathrm{O}(1)-\mathrm{La}(1)$ & $2.5880(14)$ & $\mathrm{O}(2)-\mathrm{La}(1)$ & $2.6899(15)$ \\
$\mathrm{O}(4)-\mathrm{La}(1)$ & $2.6717(15)$ & $\mathrm{O}(6)-\mathrm{La}(1)$ & $2.6278(16)$ \\
\hline
\end{tabular}

Table 3. Selected bond angles $\left(^{\circ}\right)$ for $\mathbf{1}$.

$\mathrm{O}(1)^{\mathrm{a}}-\mathrm{La}(1)-\mathrm{N}(2) \quad 118.23(5) \quad \mathrm{O}(1)-\mathrm{La}(1)-\mathrm{N}(2)^{\mathrm{a}} \quad 118.23(5)$

$\mathrm{O}(1)-\mathrm{La}(1)-\mathrm{N}(2) \quad 57.76(5) \quad \mathrm{O}(1)^{\mathrm{a}}-\mathrm{La}(1)-\mathrm{N}(2)^{\mathrm{a}} \quad 57.76(5)$

$\mathrm{N}(2)-\mathrm{La}(1)-\mathrm{N}(2)^{\mathrm{a}} \quad 128.31(7) \quad \mathrm{O}(1)-\mathrm{La}(1)-\mathrm{O}(1)^{\mathrm{a}} \quad 172.04(7)$

$\mathrm{O}(2)-\mathrm{La}(1)-\mathrm{O}(2)^{\mathrm{a}} \quad 46.98(6) \quad \mathrm{O}(6)-\mathrm{La}(1)-\mathrm{O}(4)^{\mathrm{a}} \quad 47.57(5)$

$\mathrm{O}(6)-\mathrm{La}(1)-\mathrm{O}(2) \quad 167.08(5) \quad \mathrm{O}(6)^{\mathrm{a}}-\mathrm{La}(1)-\mathrm{O}(2)^{\mathrm{a}} \quad 167.08(5)$

$\mathrm{O}(6)^{\mathrm{a}}-\mathrm{La}(1)-\mathrm{O}(2) \quad 123.99(5) \quad \mathrm{O}(6)-\mathrm{La}(1)-\mathrm{O}(2)^{\mathrm{a}} \quad 123.99(5)$

$\mathrm{O}(4)^{\mathrm{a}}-\mathrm{La}(1)-\mathrm{O}(2) \quad 126.42(5) \quad \mathrm{O}(4)-\mathrm{La}(1)-\mathrm{O}(2)^{\mathrm{a}} \quad 126.42(5)$

$\mathrm{O}(4)-\mathrm{La}(1)-\mathrm{O}(2) \quad 125.49(5) \quad \mathrm{O}(4)^{\mathrm{a}}-\mathrm{La}(1)-\mathrm{O}(2)^{\mathrm{a}} \quad 125.49(5)$

${ }^{a}$ Symmetry transformations used to generate equivalent atoms: $-\mathrm{x}, \mathrm{y},-\mathrm{z}+1 / 2$

The La-O distances range between 2.5880(14) and 2.6899(15)A. Similarly, the La-N distances range between 2.7901(16) and 2.8271(17) ̊. The coordination

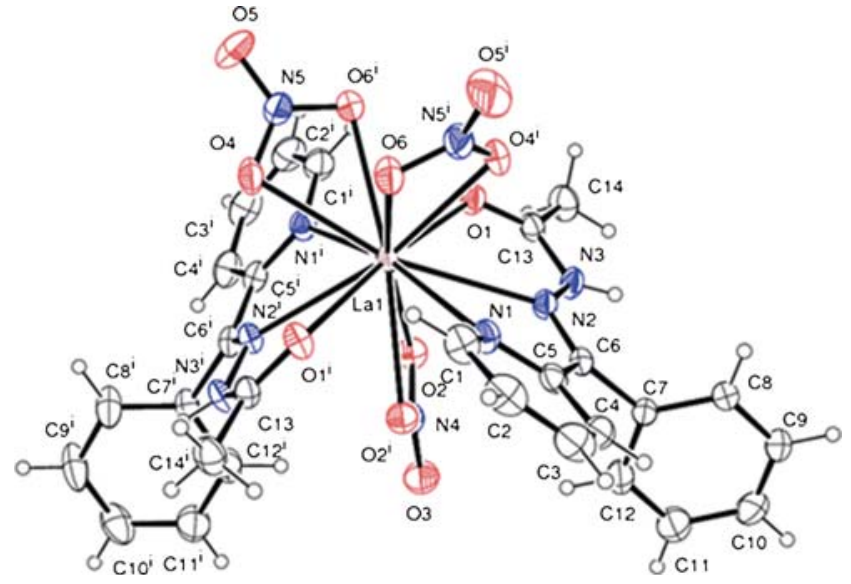

Figure 2. ORTEP view of $\left[\mathrm{La}(\mathrm{BPAH})_{2}\left(\mathrm{NO}_{3}\right)_{3}\right]$. geometry around $\mathrm{La}(\mathrm{III})$ ion is distorted icosahedrons, with six of them belong to two neutral tridentate ligands(BPAH) and six to the three bidentate nitrate 


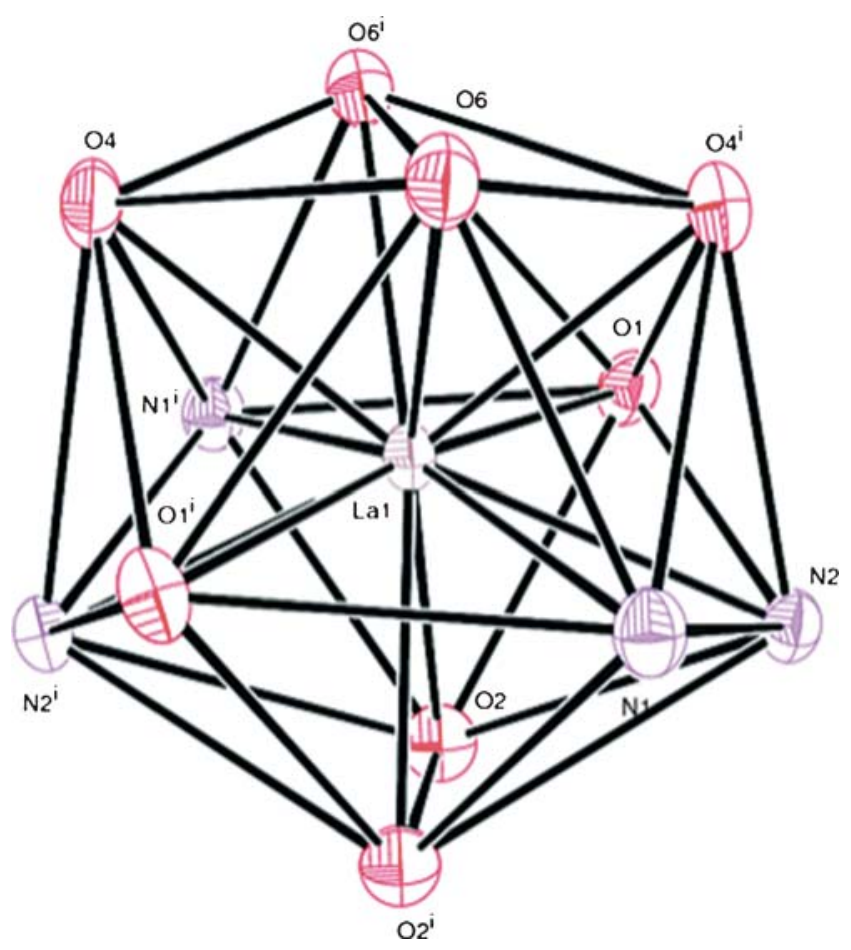

Figure 3. The coordination polyhedron around Lanthanum (III) ion.

groups. $\left[\mathrm{La}(\mathrm{BPAH})_{2}\left(\mathrm{NO}_{3}\right)_{3}\right]$ shows that the geometry of 12-coordination is distorted icosahedron in which five triangles are joined at each vertex. There are 30 edges, 12 vertices and 20 faces (i.e., $\mathrm{V}-\mathrm{E}+\mathrm{F}=$ 2 , Euler's formula, $12-30+20=2$ ). In our case the coordination polyhedron around $\mathrm{La}$ atom is distorted icosahedron and as shown in Figure 3, and analogous with the previously reported 12-coordinated lanthanide complexes. ${ }^{16,30}$

Lanthanum to BPAH Ligand donor atom bond length orders are:

La-N(pyridine $)>$ La-N(Azomethine $)>$ La$\mathrm{O}$ (Amide carbonyl).

The intra-molecular $\mathrm{C}-\mathrm{H} . . . \pi$ interaction between the phenyl ring (adjacent to the 2-pyridyl ring) and pyridine hydrogen shows a distance of $3.283 \AA$. The intra-molecular $\mathrm{N}-\mathrm{H} . . . \pi$ interaction between the phenyl ring (adjacent to the 2-pyridyl ring) and imine hydrogen shows a distance of $3.232 \AA$. X-H... $\pi$ intra molecular interactions for the lanthanum complex as shown in Figure $\mathrm{S} 1$.

The C-H... $\pi$ interactions (3.061 $\AA$ ) between methyl hydrogen and cloud of pyridine ring of neighbour molecule play an important role in the construction of 1D supramolecular chain of La complex. Details of intra and inter molecular $\mathrm{CH} . . . \pi$ interactions are given in Table 4.

In lanthanum complex, imine hydrogen behaves as a $\mathrm{H}$-bond donor towards oxygen atom (not involved in bond formation with metal) of coordinated nitrate ion $\mathrm{N}-\mathrm{H}$...O-N(nitrate) resulting in the formation of a $1 \mathrm{D}$ supra molecular chain as shown in Figure 4. Selected hydrogen bond parameters are listed in Table S1.

\subsection{Description of the molecular structure of $\left[\mathrm{Ce}(\mathrm{BPAH})_{2}\left(\mathrm{NO}_{3}\right)\left(\mathrm{H}_{2} \mathrm{O}\right)_{2}\right] 2 \mathrm{NO}_{3}$ complex}

The cerium complex has been structurally characterized by single crystal $\mathrm{X}$-ray diffraction studies. It crystallizes in orthorhombic, space group $\mathrm{P} 22_{1} 2_{1} 2_{1}$ with four monomeric complex cations i.e., $\left[\mathrm{Ce}(\mathrm{BPAH})_{2}\left(\mathrm{NO}_{3}\right)\right.$ $\left.\left(\mathrm{H}_{2} \mathrm{O}\right)_{2}\right]^{2+}$ and 8 ionic nitrates in each unit cell, as shown in Figure 5.

Crystal data and structure refinement parameters are shown in Table 1. Important bond lengths and bond angles are presented in Tables 5 and 6. ORTEP view of cerium complex together with the atom labelling scheme used is as shown in Figure 6. The BPAH ligand is coordinated to central metal atom to form two five membered rings. Two five membered rings are planar and also in one plane. Dihedral angle between the two five membered rings is $1.87-2.02^{\circ}$. Dihedral angle between the two ligand main planes is $36.33^{\circ}$.

The dihedral angle between the pyridine and phenyl ring in the same hydrazone ligand is 67.07 to $83.38^{\circ}$ indicating that the phenyl ring is twisted out of pyridine ring plane so as to avoid $\mathrm{H}-\mathrm{H}$ repulsion.

The Ce-O distances range between 2.725(3) and 2.797(2) A. Similarly the Ce-N distances range between

Table 4. Intra and Inter molecular $\mathrm{CH} . . . \pi$ interactions for $\mathbf{1}$.

\begin{tabular}{lccc}
\hline $\mathrm{Y}-\mathrm{X} \ldots \mathrm{Cg}(\mathrm{J})$ & $\mathrm{d}(\mathrm{X} \ldots \mathrm{Cg}(\mathrm{J}))$ & $\mathrm{d}(\mathrm{Y} \ldots \mathrm{Cg}(\mathrm{J}))$ & $<\mathrm{Y}-\mathrm{X} \ldots \mathrm{Cg}(\mathrm{J})$ \\
\hline Intra molecular CH... & & & \\
$\mathrm{N}(3)-\mathrm{H}(3 \mathrm{~A}) \ldots \mathrm{Cg}(1)$ & 3.283 & 3.773 & 122.30 \\
$\mathrm{C}(3)-\mathrm{H}(4) \ldots \mathrm{Cg}(1)$ & 3.232 & 3.857 & 126.42 \\
Inter molecular CH... & & & \\
$\mathrm{C}(14)-\mathrm{H}(14 \mathrm{~B}) \ldots \mathrm{Cg}(2)$ & 3.061 & 3.887 & 145.00 \\
$\mathrm{Cg}(1)=\mathrm{C} 7-\mathrm{C} 8-\mathrm{C} 9-\mathrm{C} 10-\mathrm{C} 11-\mathrm{C} 12$ & & & \\
$\mathrm{Cg}(2)=\mathrm{C} 1-\mathrm{C} 2-\mathrm{C} 3-\mathrm{C} 4-\mathrm{C} 5-\mathrm{N} 1$ & & & \\
\hline
\end{tabular}




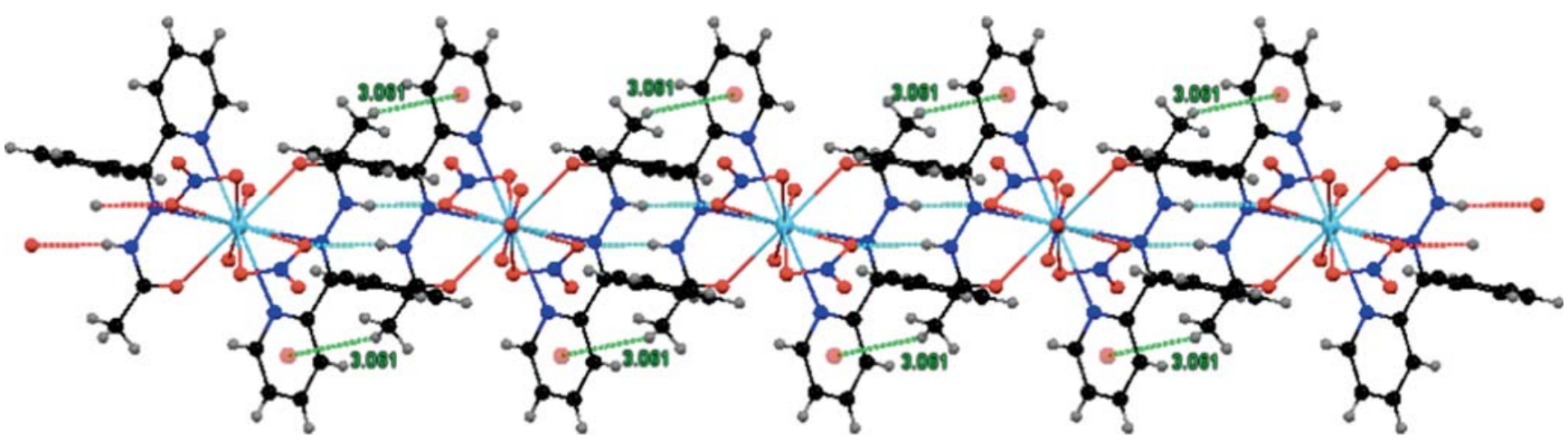

Figure 4. The 1-D structure of $\left[\mathrm{La}(\mathrm{BPAH})_{2}\left(\mathrm{NO}_{3}\right)_{3}\right]$ formed by $\mathrm{CH} . . . \pi$ and $\mathrm{N}-\mathrm{H} \ldots \mathrm{O}$ interactions.

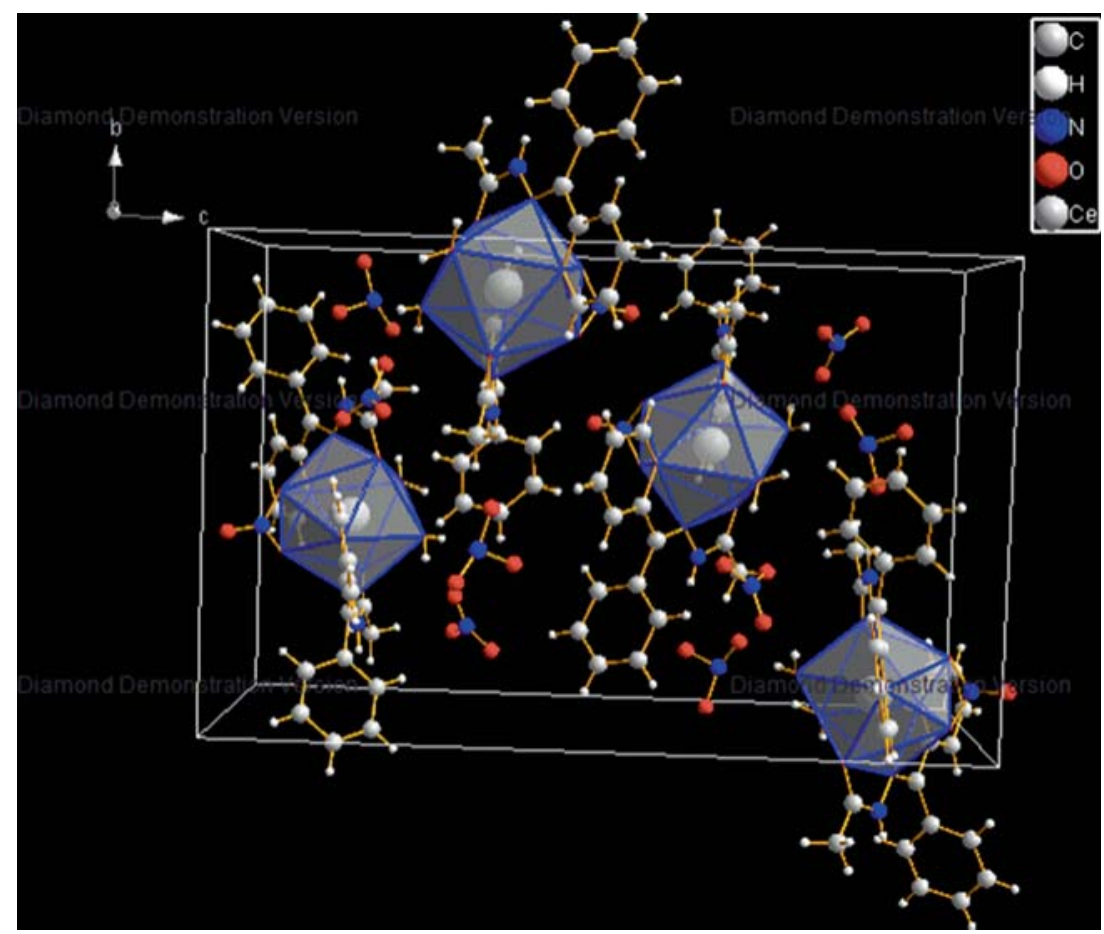

Figure 5. Unit cell structure of $\left[\mathrm{Ce}(\mathrm{BPAH})_{2}\left(\mathrm{NO}_{3}\right)\left(\mathrm{H}_{2} \mathrm{O}\right)_{2}\right] \cdot 2 \mathrm{NO}_{3}$ with bicapped square antiprism around $\mathrm{Ce}(\mathrm{III})$ centers.

Table 5. Selected bond lengths ( $\AA$ ) for the structure of 2 .

\begin{tabular}{llll}
\hline $\mathrm{N}(1)-\mathrm{Ce}(1)$ & $2.748(3)$ & $\mathrm{N}(6)-\mathrm{Ce}(1)$ & $2.725(3)$ \\
$\mathrm{N}(2)-\mathrm{Ce}(1)$ & $2.797(2)$ & $\mathrm{N}(5)-\mathrm{Ce}(1)$ & $2.738(2)$ \\
$\mathrm{O}(1)-\mathrm{Ce}(1)$ & $2.502(2)$ & $\mathrm{O}(2)-\mathrm{Ce}(1)$ & $2.484(2)$ \\
$\mathrm{O}(4)-\mathrm{Ce}(1)$ & $2.570(3)$ & $\mathrm{O}(3)-\mathrm{Ce}(1)$ & $2.585(3)$ \\
$\mathrm{O}(7)-\mathrm{Ce}(1)$ & $2.499(3)$ & $\mathrm{O}(6)-\mathrm{Ce}(1)$ & $2.536(2)$ \\
\hline
\end{tabular}

2.484(2) and 2.585(3) $\AA$. Ce atom is surrounded by 10 coordinated donor atoms. Six of them belong to two neutral tridentate ligands, two are from the two mono dentate aqua ligands and other two are from the one bidentate nitrate group. The polyhedron around $\mathrm{Ce}$ forms slightly distorted bicapped square anti- prism as shown in Figure 7. In cerium complex, $\mathrm{O}(1), \mathrm{O}(4), \mathrm{N}(1)$, $\mathrm{O}(7)$ define one of the square face of the polyhedron
Table 6. Selected bond angles $\left({ }^{\circ}\right)$ for the structure of 2.

$\begin{array}{lrlr}\mathrm{N}(1)-\mathrm{Ce}(1)-\mathrm{N}(2) & 57.13(7) & \mathrm{N}(6)-\mathrm{Ce}(1)-\mathrm{N}(5) & 58.46(8) \\ \mathrm{O}(1)-\mathrm{Ce}(1)-\mathrm{N}(1) & 115.63(7) & \mathrm{O}(2)-\mathrm{Ce}(1)-\mathrm{N}(6) & 117.70(8) \\ \mathrm{O}(1)-\mathrm{Ce}(1)-\mathrm{N}(2) & 58.50(7) & \mathrm{O}(2)-\mathrm{Ce}(1)-\mathrm{N}(5) & 59.31(8) \\ \mathrm{O}(7)-\mathrm{Ce}(1)-\mathrm{N}(1) & 80.14(10) & \mathrm{O}(6)-\mathrm{Ce}(1)-\mathrm{N}(6) & 73.76(9) \\ \mathrm{O}(6)-\mathrm{Ce}(1)-\mathrm{N}(1) & 143.06(9) & \mathrm{O}(7)-\mathrm{Ce}(1)-\mathrm{N}(6) & 138.05(9) \\ \mathrm{O}(3)-\mathrm{Ce}(1)-\mathrm{N}(1) & 68.99(9) & \mathrm{O}(3)-\mathrm{Ce}(1)-\mathrm{N}(6) & 74.46(9) \\ \mathrm{O}(4)-\mathrm{Ce}(1)-\mathrm{N}(1) & 74.66(9) & \mathrm{O}(4)-\mathrm{Ce}(1)-\mathrm{N}(6) & 71.55(8) \\ \mathrm{O}(2)-\mathrm{Ce}(1)-\mathrm{N}(1) & 70.87(8) & \mathrm{O}(1)-\mathrm{Ce}(1)-\mathrm{N}(6) & 75.77(8) \\ \mathrm{N}(6)-\mathrm{Ce}(1)-\mathrm{N}(1) & 141.09(9) & \mathrm{O}(2)-\mathrm{Ce}(1)-\mathrm{O}(1) & 151.64(9)\end{array}$

and $\mathrm{O}(2), \mathrm{O}(6), \mathrm{N}(6), \mathrm{O}(3)$ define the other face. Azomethine nitrogen atoms are on the bicapped positions, which are similar to previously reported 10- coordinated lanthanide (III) complexes. ${ }^{17,31}$ 


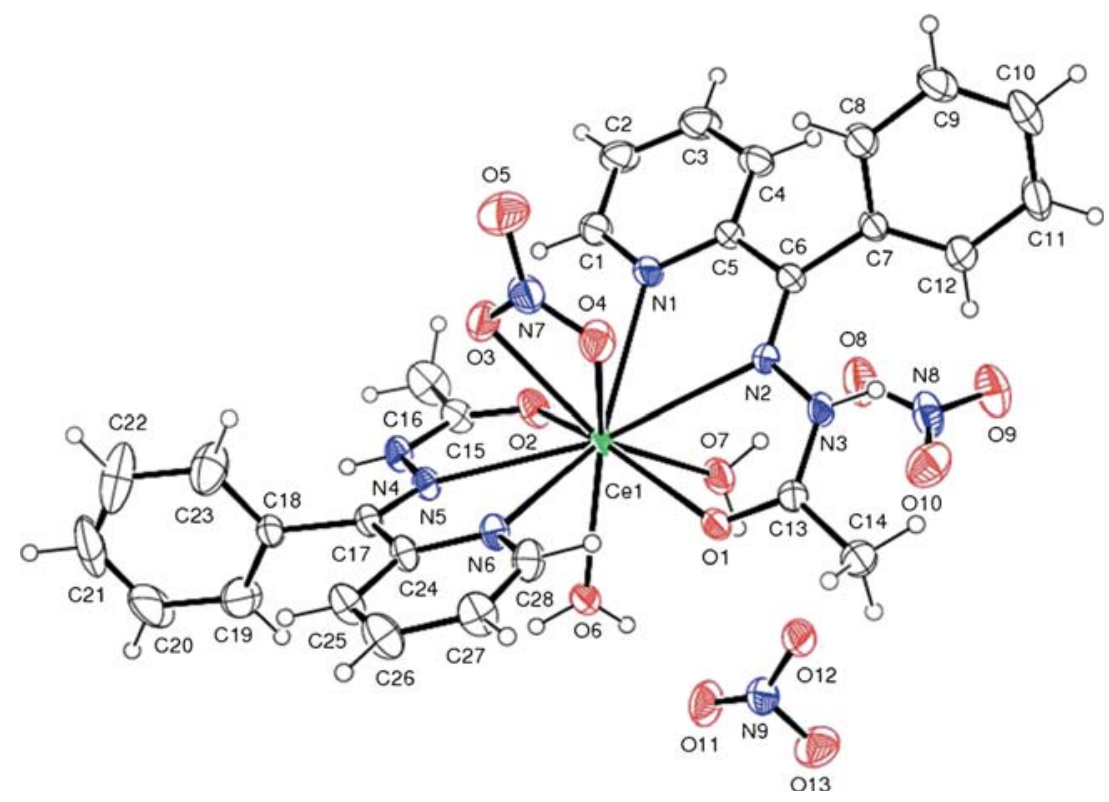

Figure 6. ORTEP view of $\left[\mathrm{Ce}(\mathrm{BPAH})_{2}\left(\mathrm{NO}_{3}\right)\left(\mathrm{H}_{2} \mathrm{O}\right)_{2}\right] \cdot 2 \mathrm{NO}_{3}$.

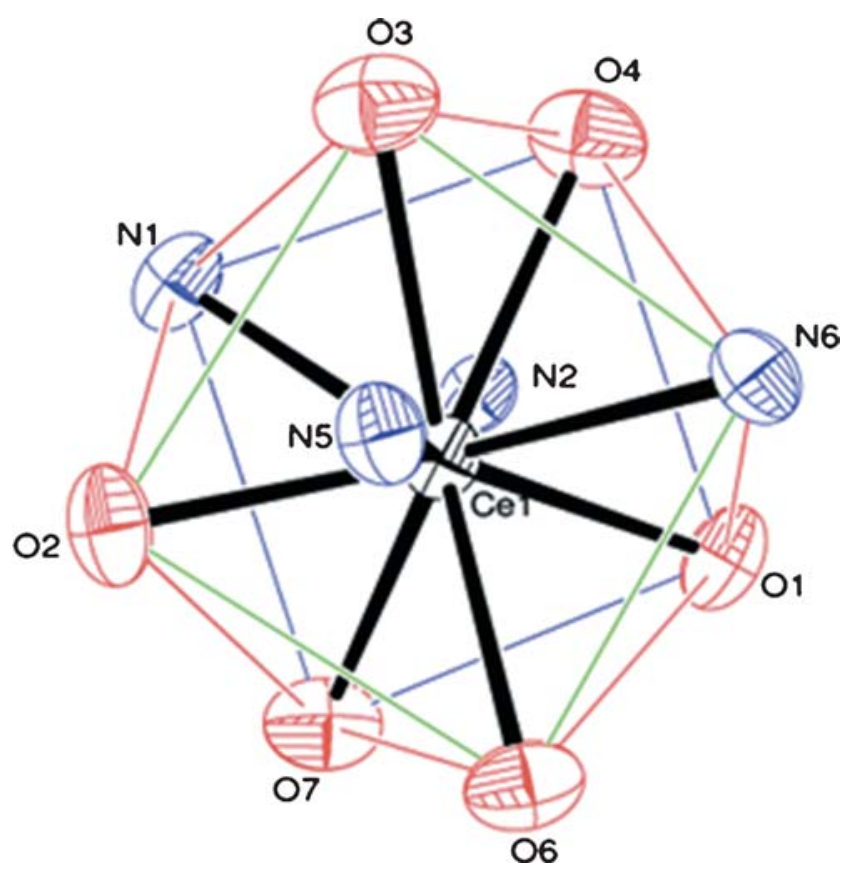

Figure 7. The coordination polyhedron around Cerium (III) ion.

The intra-molecular X-H... $\pi$ interaction between the phenyl ring (adjacent to the 2-pyridyl ring) and pyri-

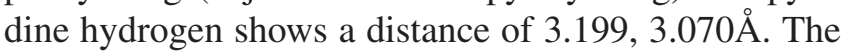
intra-molecular $\mathrm{N}-\mathrm{H} . . . \pi$ interaction between the phenyl ring (adjacent to the 2-pyridyl ring) and imine hydrogen shows a distance of $3.164,3.417 \AA$. X-H... $\pi$ intra molecular interactions for the Cerium complex is shown in Figure S2 (in Supplementary Information).

Another interesting feature of the $\left[\mathrm{Ce}(\mathrm{BPAH})_{2}\left(\mathrm{NO}_{3}\right)\right.$ $\left.\left(\mathrm{H}_{2} \mathrm{O}\right)_{2}\right] \cdot 2 \mathrm{NO}_{3}$ complex is the presence two types of
$\mathrm{CH} . . . \pi$ interactions (Figure 8). One type of $\mathrm{CH} . . . \pi$ interaction exist between the hydrogen atom of pyridine ring and pyridine ring of neighbour molecule, with $\mathrm{CH} . . . \pi$ distance of $3.173 \AA$ for $\mathrm{C}(2)-\mathrm{H}(2) \ldots \mathrm{Cg}(5)[\mathrm{Cg}(5)$ is centroid for C24-C25-C26-C27-C28-N6 ring], another type of $\mathrm{CH} . . . \pi$ interaction exist between the hydrogen atom of phenyl ring(benzoyl) and pyridine ring of the neighbour molecule, with $\mathrm{CH} . . . \pi$ distance of $3.132 \AA$ for $\mathrm{C}(11)-\mathrm{H}(11) \ldots \mathrm{Cg}(6)[\mathrm{Cg}(6)$ is centroid for $\mathrm{C} 24-$ C25-C26-C27-C28-N6 ring]. Details of intermolecular $\mathrm{CH} . . . \pi$ interactions are given in Table 7 .

In cerium complex, intermolecular $\mathrm{N}-\mathrm{H} \cdots \mathrm{O}$ and $\mathrm{O}-$ $\mathrm{H}$. . O type of hydrogen bonds exist between imine and coordinated water $\mathrm{H}$ atoms as donors and oxygen atom of ionic nitrates as acceptors. Selected hydrogen bond lengths and bond angles are given in Table S2 (in Supplementary Information). View of the hydrogen bonded network is shown in Figure S3 (in Supplementary Information).

\subsection{Hirshfeld surface analysis}

The Hirshfeld surface mapped over $d_{\text {norm }}$ displays the intermolecular $\mathrm{NH}$... $\mathrm{O}_{\text {(nitrate) }}$ interactions as bright red and medium red colour indicates $\mathrm{CH}_{\text {(benzoyl/pyridine) } \cdots}$ $\mathrm{O}_{\text {(nitrate) }}$ interactions on the dnorm surface in lanthanum complex which is shown in Figure 9.

The Hirshfeld surface mapped over $d_{\text {norm }}$ surface in cerium complex is also shown in Figure 9 where the intermolecular $\mathrm{OH}_{\text {(coordinatewater) } \ldots \mathrm{O}_{\text {(ionicnitrate) }} \text { interac- }}$ tions are displayed as bright red and medium red colour indicates $\mathrm{NH}_{\text {(imine) }} \ldots \mathrm{O}_{\text {(ionicnitrate) }}$ interactions and 


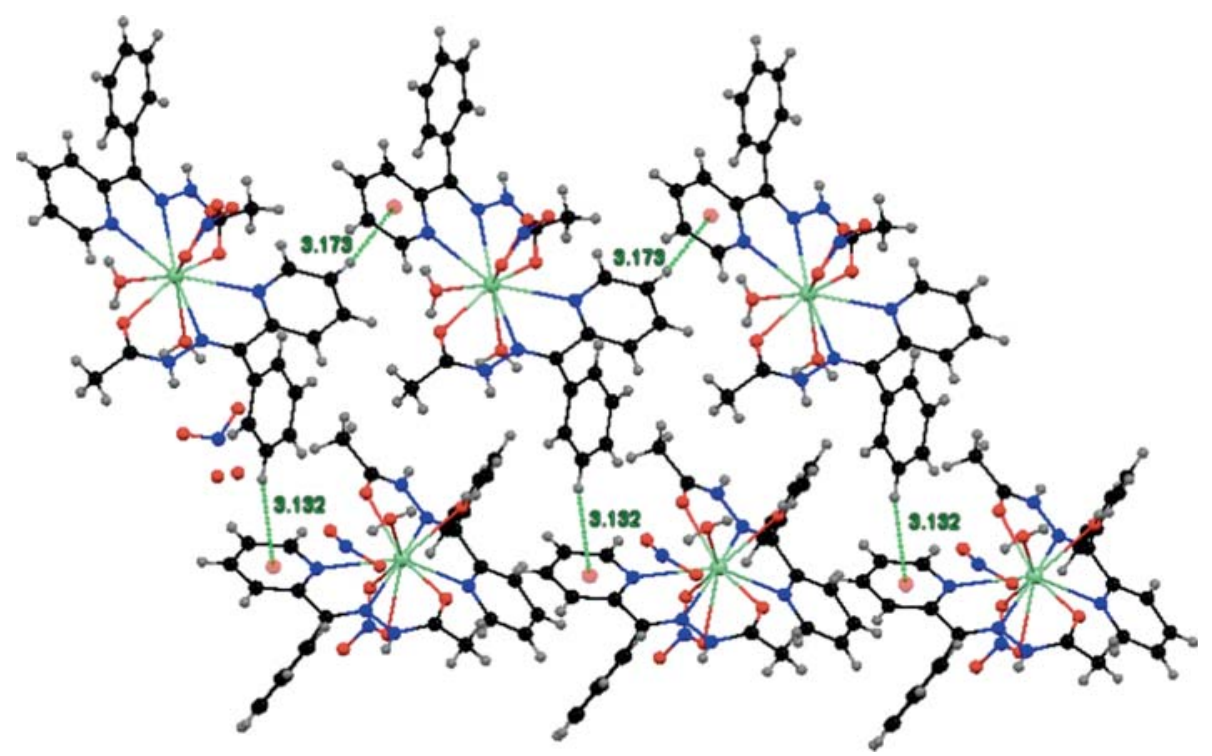

Figure 8. The 2-D structure of $\left[\mathrm{Ce}(\mathrm{BPAH})_{2}\left(\mathrm{NO}_{3}\right)\left(\mathrm{H}_{2} \mathrm{O}\right)_{2}\right] \cdot 2 \mathrm{NO}_{3}$ formed by two kinds of C-H... $\pi$ interactions.

Table 7. Intra and inter molecular $\mathrm{CH} . . . \pi$ interactions for 2.

\begin{tabular}{lccc}
\hline $\mathrm{Y}-\mathrm{X} \ldots \mathrm{Cg}(\mathrm{J})$ & $\mathrm{d}(\mathrm{X} \ldots \mathrm{Cg}(\mathrm{J}))$ & $\mathrm{d}(\mathrm{Y} \ldots \mathrm{Cg}(\mathrm{J}))$ & $<\mathrm{Y}-\mathrm{X} \ldots \mathrm{Cg}(\mathrm{J})$ \\
\hline & Intra molecular CH.. & \\
$\mathrm{N}(4)-\mathrm{H}(4 \mathrm{~A}) \ldots \mathrm{Cg}(3)$ & 3.164 & 3.768 & 130.81 \\
$\mathrm{C}(25)-\mathrm{H}(25) \ldots \mathrm{Cg}(3)$ & 3.199 & 3.835 & 127.36 \\
$\mathrm{~N}(3)-\mathrm{H}(3 \mathrm{~A}) \ldots \mathrm{Cg}(4)$ & 3.417 & 3.954 & 123.39 \\
$\mathrm{C}(4)-\mathrm{H}(4) \ldots \mathrm{Cg}(4)$ & 3.070 & 3.170 & 127.53 \\
& & & \\
$\mathrm{C}(2)-\mathrm{H}(2) \ldots \mathrm{Cg}(5)$ & 3.551 & 106.49 \\
$\mathrm{C}(11)-\mathrm{H}(11) \ldots \mathrm{Cg}(6)$ & 3.988 \\
$\mathrm{Cg}(3)=\mathrm{C} 18-\mathrm{C} 19-\mathrm{C} 20-\mathrm{C} 21-\mathrm{C} 22-\mathrm{C} 23$ & & \\
$\mathrm{Cg}(4)=\mathrm{C} 7-\mathrm{C} 8-\mathrm{C} 9-\mathrm{C} 10-\mathrm{C} 11-\mathrm{C} 12$ & & \\
$\mathrm{Cg}(5)=\mathrm{C} 24-\mathrm{C} 25-\mathrm{C} 26-\mathrm{C} 27-\mathrm{C} 28-\mathrm{N} 6$ & & \\
$\mathrm{Cg}(6)=\mathrm{C} 1-\mathrm{C} 2-\mathrm{C} 3-\mathrm{C} 4-\mathrm{C} 5-\mathrm{N} 1$ & & \\
\end{tabular}

$\mathrm{CH}$ (benzyol/pyridine) $\ldots \mathrm{O}_{\text {(ionicnitrate) }}$ interactions on the dnorm surface.

In Figure 10, the left picture is the Hirshfeld surface mapped with shape index for lanthanum complex. The two pyridine aromatic rings are the $\mathrm{C}-\mathrm{H}$... $\pi$ acceptors that interact with $\mathrm{C}-\mathrm{H}$ groups from neighbouring molecules. These two pyridine acceptors correspond to the two large red spots in the left of picture of Figure 10. Meanwhile, two C-H hydrogen's from the acetyl group act as $\mathrm{C}-\mathrm{H}$... $\pi$ donors to interact with the pyridine rings of neighbouring molecules, corresponding to the circled blue areas in the left of picture of Figure 10.

The right picture in Figure 10 is the Hirshfeld surface mapped with shape index for the cerium complex. The two pyridine aromatic rings acts as $\mathrm{C}-\mathrm{H}$... $\pi$ acceptors as well as $\mathrm{C}-\mathrm{H} . . . \pi$ donors. C-H hydrogen's from the phenyl group act as $\mathrm{C}-\mathrm{H}$... $\pi$ donors to interact with the pyridine ring of neighbouring molecule, corresponding to the circled blue areas in the right of picture of Figure 10.

This decomposition enables separation of contributions from different interaction types, which overlap in the full fingerprint plot. The decomposition of the fingerprint plot shows that C...H/H...C contacts comprise $17.1 \%$ and $13.2 \%$ of the total Hirshfeld surface area for $\mathrm{La}$ and $\mathrm{Ce}$ complex respectively. The region corresponds to all $\mathrm{C}-\mathrm{H}$...C interactions of which $\mathrm{C}-$ $\mathrm{H} . . . \pi$ appears in the fingerprint plot in a characteristic manner.

Hirshfeld surface of $\mathrm{La}$ and $\mathrm{Ce}$ complexes does not show 'bow tie' pattern shape-index surfaces (Figure 11), and also on finger print plot does not show 'stacking kite' pattern and it can clearly be seen that it indicates absence of $\pi-\pi$ stacking interactions. ${ }^{32,33}$ 

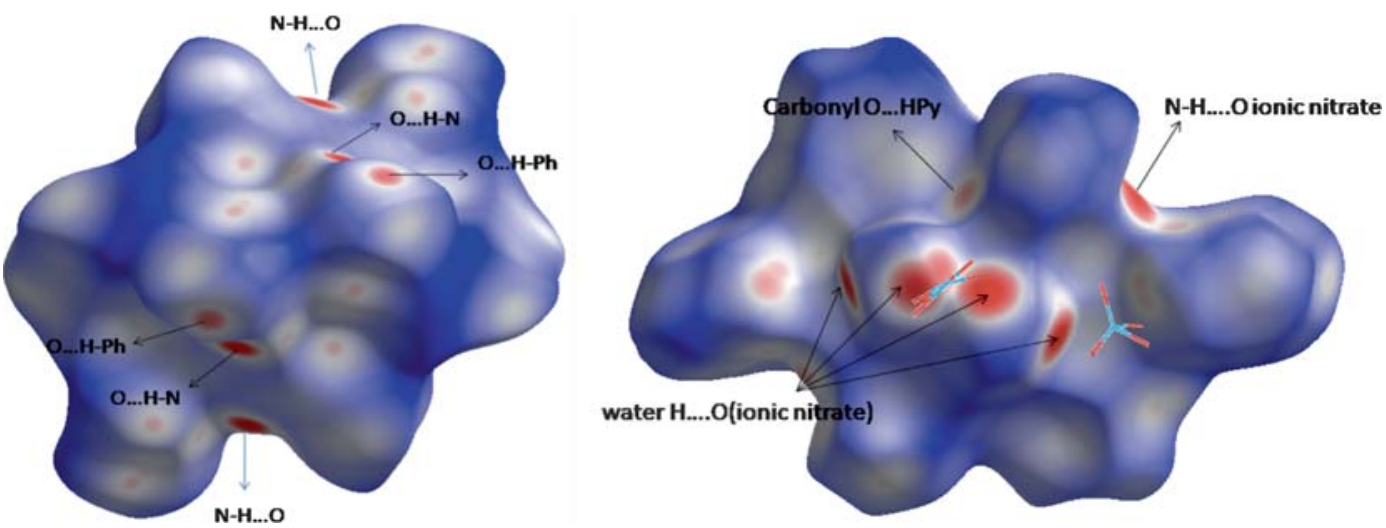

Figure 9. Hirshfeld surface mapped $d_{\text {norm }}$ for $\left[\mathrm{La}(\mathrm{BPAH})_{2}\left(\mathrm{NO}_{3}\right)_{3}\right](\mathrm{Left})$ and $\left[\mathrm{Ce}(\mathrm{BPAH})_{2}\left(\mathrm{NO}_{3}\right)\left(\mathrm{H}_{2} \mathrm{O}\right)_{2}\right] .2 \mathrm{NO}_{3}(\mathrm{Right})$.
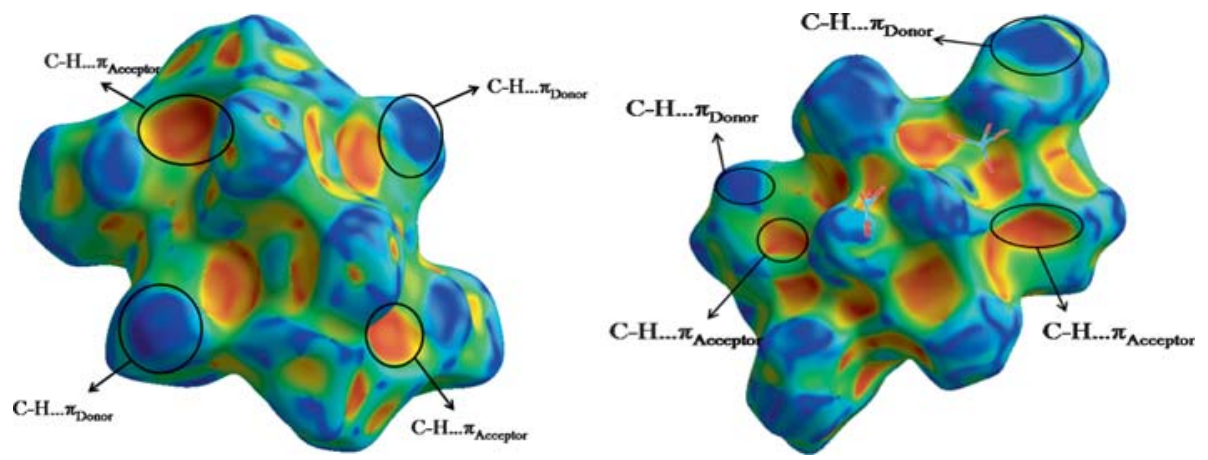

Figure 10. Hirshfeld surface mapped shape index for $\left[\mathrm{La}(\mathrm{BPAH})_{2}\left(\mathrm{NO}_{3}\right)_{3}\right]$ (Left) and $\left[\mathrm{Ce}(\mathrm{BPAH})_{2}\left(\mathrm{NO}_{3}\right)\left(\mathrm{H}_{2} \mathrm{O}\right)_{2}\right] \cdot 2 \mathrm{NO}_{3}$ (Right).

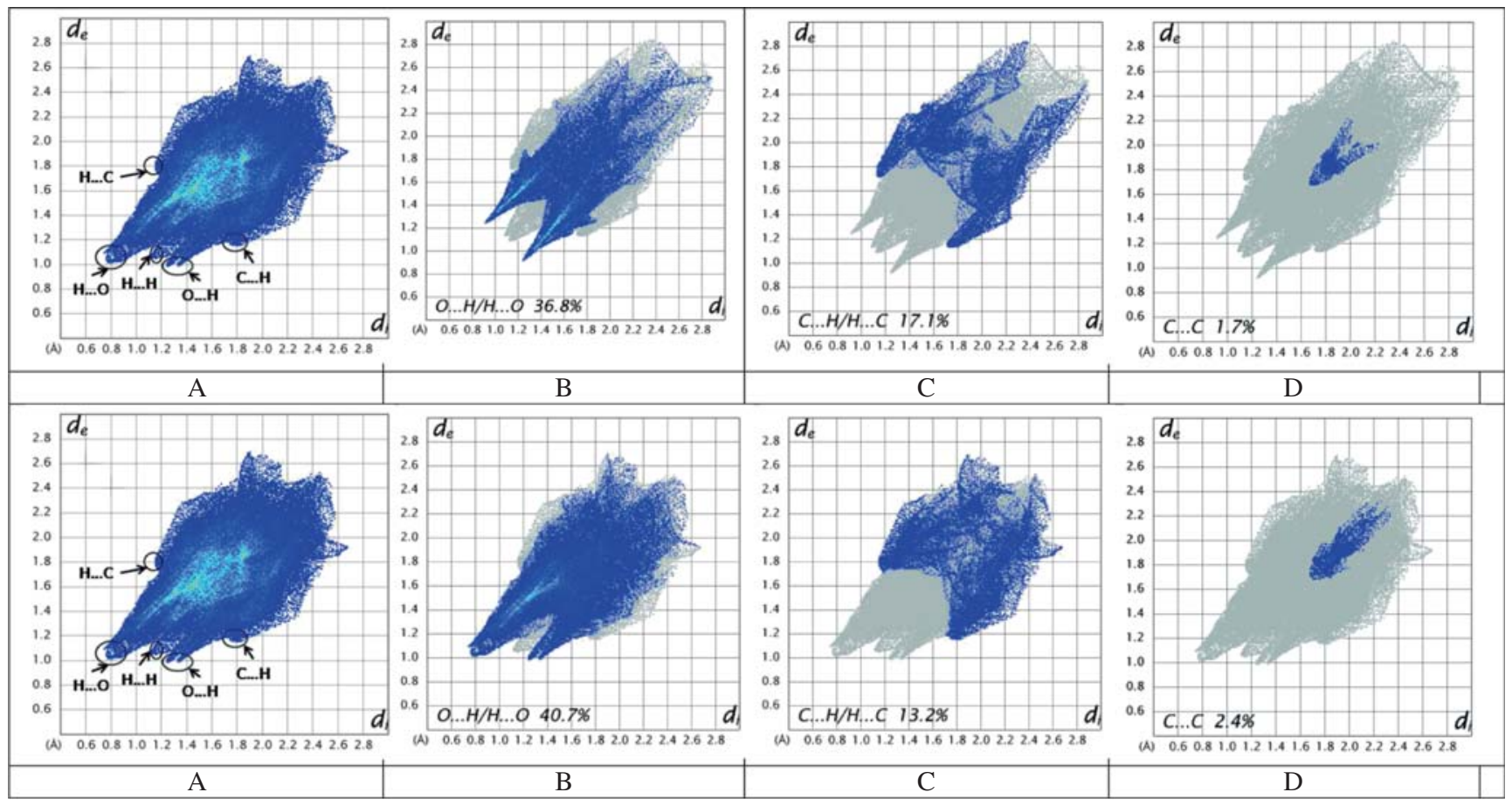

Figure 11. 2D fingerprint plots of $\left[\mathrm{La}(\mathrm{BPAH})_{2}\left(\mathrm{NO}_{3}\right)_{3}\right]$ (top) and $\left[\mathrm{Ce}(\mathrm{BPAH})_{2}\left(\mathrm{NO}_{3}\right)\left(\mathrm{H}_{2} \mathrm{O}\right)_{2}\right] .2 \mathrm{NO}_{3}$ (bottom), full (left) and resolved into $\mathrm{OH} / \mathrm{HO}, \mathrm{CH} / \mathrm{CH}$ and $\mathrm{C} / \mathrm{C}$ contacts showing percentages of contacts contributed to the total Hirshfeld surface area of molecule. 
Table 8. Hirshfeld surface analysis of some related complexes showing the percentages of contacts contributed to the total Hirshfeld surface area.

\begin{tabular}{lcccccc}
\hline Compound & $\mathrm{O} \ldots \mathrm{H} / \mathrm{H} \ldots \mathrm{O}(\%)$ & $\mathrm{H} \ldots \mathrm{H}(\%)$ & $\mathrm{C} \ldots \mathrm{H} / \mathrm{H} \ldots \mathrm{C}(\%)$ & $\mathrm{C} \ldots \mathrm{C}(\%)$ & $\mathrm{C} \ldots \mathrm{O} / \mathrm{O} \ldots \mathrm{C}(\%)$ & Ref \\
\hline$\left[\mathrm{La}(\mathrm{BPAH})_{2}\left(\mathrm{NO}_{3}\right)_{3}\right]$ & 36.8 & 39.1 & 17.1 & 1.7 & 1.3 & This work \\
{$\left[\mathrm{Ce}(\mathrm{BPBH})_{2}\left(\mathrm{NO}_{3}\right)_{3}\right]$} & 27.3 & 41.4 & 19.9 & 3.6 & 4.2 & 16 \\
{$\left[\mathrm{Ce}(\mathrm{BPAH})_{2}\left(\mathrm{NO}_{3}\right)\left(\mathrm{H}_{2} \mathrm{O}\right)_{2}\right] 2 \mathrm{NO}_{3}$} & 40.7 & 36.9 & 13.2 & 2.4 & 2.8 & This work \\
{$\left[\mathrm{Ce}(\mathrm{APAH})_{2}\left(\mathrm{NO}_{3}\right)\left(\mathrm{H}_{2} \mathrm{O}\right)_{2}\right] 2 \mathrm{NO}_{3} . \mathrm{H}_{2} \mathrm{O}$} & 50.4 & 29.2 & 10.1 & 2.5 & 2.0 & 17 \\
{$\left[\mathrm{Sm}(\mathrm{APAH})_{2}\left(\mathrm{NO}_{3}\right)\left(\mathrm{H}_{2} \mathrm{O}\right)_{2}\right] 2 \mathrm{NO}_{3} .2 \mathrm{H}_{2} \mathrm{O}$} & 41.8 & 39.7 & 9.4 & 2.0 & 2.6 & 17 \\
\hline
\end{tabular}

However some carbon-carbon interactions are present which comprises $1.7 \%$ and $2.4 \%$ of the total Hirshfed surface area of $\mathrm{La}$ and $\mathrm{Ce}$ complexes. We have compared Hirshfeld surface analysis of some related lanthanide complexes with similar ligands ${ }^{16,17}$ and gathered the results in Table 8.

\subsection{DNA binding and cleavage studies}

UV-Vis spectral change (titration) experiment is a most powerful technique to investigative the interaction of DNA with metal complexes. ${ }^{34}$ The binding interaction of complexes with CT-DNA was monitored by comparing their absorption spectra with and without CTDNA. In the absorption spectra of BPAH ligand, La and Ce complex exhibit an intense band at 291, 304 and $304 \mathrm{~nm}$ exhibit hypochromism ( $\mathrm{H} \%)$ of about 4.02, 13.51 and $11.71 \mathrm{~nm}$ and bathochromism of about 1 , 1 , and $1.5 \mathrm{~nm}$ respectively. These bands are attributed to $\pi \rightarrow \pi^{*}$ transition. Absorption spectra of complexes $\mathbf{1}$ and $\mathbf{2}$ in the absence and in the presence of increasing concentration of CT-DNA are given in Figures S4 and S5 (in Supplementary Information), respectively. The intrinsic binding constants $\left(\mathrm{K}_{\mathrm{b}}\right)$ are found to be $0.65,3.67$ and $3.07 \times 10^{5} \mathrm{M}^{-1}$ for BPAH (ligand), La and Ce complexes respectively. Such a small change in $\lambda_{\max }$ is more in keeping with groove binding, leading to small perturbations. The $\mathrm{K}_{\mathrm{b}}$ value obtained here is lower than that reported for classical intercalator for ethidium bromide and $\left[\mathrm{Ru}(\mathrm{phen})_{2} \mathrm{DPPZ}\right]^{2+}$ whose binding constants have been found to be in the order $\left(10^{6}-10^{7} \mathrm{M}^{-1}\right) .^{35,36}$ The observed binding constants are in accordance with groove binding with DNA as reported in the literature. ${ }^{37,38}$ DNA cleavage activity of complexes 1 and 2 are shown in Figures S6 and $\mathrm{S} 7$ respectively. The cleavage activity increases with increasing concentration of complex. In the presence of $\mathrm{H}_{2} \mathrm{O}_{2}$, slight increase in the cleavage of DNA occurs in the case of Ce complex, which may be due to the reaction of hydroxyl radical (produced in situ) with DNA like Fenton mechanism. ${ }^{39}$ These hydroxyl free radicals participate in the oxidation of the deoxyribose moiety.

\section{Conclusions}

Lanthanide complexes of 2-benzoylpyridine acetylhydrazone(BPAH) have been synthesized and characterized. Physico-chemical and spectral studies revealed the formula of complexes to be $\left[\mathrm{La}(\mathrm{BPAH})_{2}\left(\mathrm{NO}_{3}\right)_{3}\right]$ and $\left[\mathrm{Ce}(\mathrm{BPAH})_{2}\left(\mathrm{NO}_{3}\right)\left(\mathrm{H}_{2} \mathrm{O}\right)_{2}\right] .2 \mathrm{NO}_{3}$ respectively. BPAH acts as neutral tridentate ligand and $\mathrm{NO}_{3}^{-}$acts as bidentate ligand. The structure of $\left[\mathrm{La}(\mathrm{BPAH})_{2}\left(\mathrm{NO}_{3}\right)_{3}\right]$ and $\left[\mathrm{Ce}(\mathrm{BPAH})_{2}\left(\mathrm{NO}_{3}\right)\left(\mathrm{H}_{2} \mathrm{O}\right)_{2}\right] .2 \mathrm{NO}_{3}$ complexes are determined by single crystal X-ray diffraction studies. In Ce complex, metal is 10-coordinate whereas in La complex, the light metal with more ionic radius assumes 12- coordination. Lanthanides complexes show variable (6-12) coordination numbers. However, coordination number 9 is the most predominant. Coordination numbers below 6 are found only with very bulky ligands, Coordination numbers 7, 8 and 9 being more characteristic of lanthanide complexes. However, coordination numbers of 10 and above are scarce.

Absorption titrations suggest groove binding of complexes with DNA. In the presence of $\mathrm{H}_{2} \mathrm{O}_{2}$ the Ce complex cleave DNA effectively.

\section{Supplementary Information (SI)}

CCDC 945920 \& CCDC 917696 contains the supplementary crystallographic data for $\mathrm{La}$ and Ce complexes. These data can be obtained free of charge via http:// www.ccdc.cam.ac.uk/conts/retrieving.html, or from the Cambridge Crystallographic Data Centre, 12 Union Road, Cambridge CB2 1EZ, UK; fax: +44 1223336 033; or e-mail: deposit@ccdc.cam.ac.uk. Figures S1 and $\mathrm{S} 2$ shows the $\mathrm{X}-\mathrm{H} . . . \pi$ intra molecular interactions for the $\mathrm{La}$ and $\mathrm{Ce}$ complexes respectively, Figure S3 shows the hydrogen bond network of Ce complex, Figures S4 and S5 shows the absorption spectra of La and Ce complexes respectively and Figures S6 and S7 show nuclease activity of $\mathrm{La}$ and Ce complexes respectively Tables S1 and S2 lists the hydrogen bonds $(\AA)$ and angles $\left(^{\circ}\right)$ for $\mathrm{La}$ and $\mathrm{Ce}$ complexes respectively. "Supplementary information is available at www.ias.ac.in/ chemsci". 


\section{Acknowledgements}

One of the authors (K. Raja) is thankful to UGC, New Delhi for the award Project Fellow. The authors are thankful to UGC, New Delhi [Sanction No. Lr.No.F 4080/2011(SR)] for financial support. KHR is thankful to U.G.C for sanction of one time financial grant [Sanction No. F 19-106/2013(BSR)]. We are also thankful to SAIF, IIT-Madras for providing x-ray crystallographic data. The authors also thank UGC and DST for providing equipment facility under SAP and FIST programs respectively.

\section{References}

1. Feng J and Zhang H 2013 Chem. Soc. Rev. 42387

2. Shinoda S and Tsukube H 2011 Analyst 136431

3. Hussain A and Chakravarty A R 2012 J. Chem. Sci. 1241327

4. Shanoon R D 1976 Acta Crystallogr. A 32751

5. Caravan P, Ellison J J, McMurry T J and Lauffer R B 1999 Chem. Rev. 992293

6. Meade T J, Moats R A and Fraser S E 1997 Angew. Chem. Int. Ed. 36726

7. Cawthray J F, Weekes D M, Sivak O, Creagh A L, Ibrahim F, Iafrate M, Haynes C A, Wasan K M and Orvig C 2015 Chem. Sci. 66439

8. Fricker S P 2006 Chem. Soc. Rev. 35524

9. Easmon J, Purstinger G, Thies K S, Heinisch G and Hofmann J 2006 J. Med. Chem. 496343

10. Angel A R D, Gabrieli I P, Jans B I, Pryscila R D, Raquel G S, Oscar E P, Eduardo E C, Willian R R and Helosia B 2012 Eur. J. Med. Chem. 50163

11. Angel A R D, Lorena F V, Isolda C M, Fernanda B C, Nivaldo L S and Heloisa B 2010 J. Braz. Chem. Soc. 211247

12. Paul V B, Gregory J W, Philip C S, Danuta S K and Des R R 2008 J. Biol. Inorg. Chem. 13107

13. Kulkarni A, Patil S A and Badami P S 2009 Eur. J. Med. Chem. 442904

14. Hussain A, Gadadhar S, Goswami T K, Karande A A and Chakravarty A R 2012 Dalton Trans. 41885

15. Mondala B, Sena B, Zangrandob E and Chattopadhyaya P 2014 J. Chem. Sci. 1261115

16. Raja K, Suseelamma A and Hussain Reddy K 2016 J. Chem. Sci. 12823
17. Raja K, Suseelamma A and Hussain Reddy K 2015 J. Iran. Chem. Soc. 121473

18. Despaigne A A R, Da Silva J G, Do Carmo A C M, Piro O E, Castellano E E and Beraldo H 2009 J. Mol. Struc. 92097

19. Siemens., SMART., SAINT., 1996. Area Detector Control and Integration Software, Siemens Analytical X-ray Instruments Inc. Madison, Wisconsin, USA

20. Sheldrick G M 1990 Acta Cryst. A 46467

21. Sheldrick G M 1997 In SHELXS-97 Program for the Solution of Crystal Structures (Germany: University of Gottingen)

22. Brandenburg $\mathrm{K}$ and Putz H 2004 DIAMOND version 3.0 Crystal Impact, GbR, Postfach 1251, D-53002 Bonn, Germany

23. Farrugia L J 1997 J. Appl. Crystallogr. 30565

24. Wolff S K, Grimwood D J, McKinnon J J, Turner M J, Jayatilaka D and Spackman M A 2012 In Crystal Explorer 3.1 (Crawley: University of Western Australia)

25. Spackman M A and McKinnon J J 2002 Cryst. Eng. Comm 4378

26. Geary W J 1971 Coord. Chem. Rev. 781

27. Nakamoto K 1986 In Infrared and Raman Spectra of Inorganic and Coordination Compounds ( $4^{\text {th }}$ edn.) (New York: Wiley)

28. Curtis N F and Curtis Y M 1965 Inorg. Chem. 4804

29. Yan P, Sun W, Li G, Nei C, Gao T and Yue Z 2007 J. Coord. Chem. 601973

30. Paschalidis D G, Tossidis I A and Gdaniec M 2000 Polyhedron 192629

31. Paschalidis D G and Gdnaiec M 2004 Struct. Chem. 15605

32. Małecka M and Budzise E 2014 Cryst. Eng. Comm. 166654

33. Mahmoudi G, Bauza A, Antonio R D, Piotr G, Werner $\mathrm{K}$ and Antonio F 2016 Cryst. Eng. Comm 18102

34. Barton J K, Danishefsky A T and Goldberg J M 1984 J. Am. Chem. Soc. 1062172

35. Cory M, McKee D D, Kagan J, Henry D W and Miller J A 1985 J. Am. Chem. Soc. 1072528

36. Waring M J 1965 J. Mol. Biol. 13269

37. Ganessan V and Unni Nair B 2003 J. Inorg. Biochem. 94121

38. Ramakrishnan S, Suresh E, Riyasdeen A, Akbarsha M A and Palaniandavar M 2011 Dalton Trans. 3245

39. Song Y M, Xu J P, Ding L, Hou Q, Liu J W and Zhu Z L 2005 J. Inorg. Biochem. 103396 